\title{
Examples of Ecotones and Paragenese in the Vegetation Cover of the Bailkalian Siberia
}

\author{
Alexander P. Sizykh1 ${ }^{*}$, Svetlana V. Sizykh ${ }^{2}$ \\ ${ }^{1}$ Siberian Institute of Plant Physiology and Biochemistry, Siberian Branch of Russian Academy of Sciences, \\ Irkutsk, Russia \\ ${ }^{2}$ Botanic Garden, Irkutsk State University, Irkutsk, Russia \\ Email: ${ }^{*}$ Alexander.sizykh@gmail.com
}

Received 27 August 2014; revised 15 September 2014; accepted 28 September 2014

Copyright (C) 2014 by authors and Scientific Research Publishing Inc.

This work is licensed under the Creative Commons Attribution International License (CC BY).

http://creativecommons.org/licenses/by/4.0/

(c) (i) Open Access

\begin{abstract}
Changes in vegetation structure in environments contact community characterize the ecotones and paragenese inside zonal vegetation site or altitude belt as of concrete environments while differences of cenotic structures of communities between zones or between altitude belts as well. The aim of this work was research of structural-dynamic organization of phytocenoses forming under the conditions of environments contact and mountain tundra, forests (zonal taiga) and extrazonal steppes, zonal forest steppes of some areas at the Baikalian Siberia, Eastern Siberia of Russia.
\end{abstract}

\section{Keywords}

Baikalian Siberia, Zonal and Extrazonal Vegetation Communities, Altitude Belts, Ecotones, Paragenese

\section{Introduction}

Numerous researchers paid much attention to the problem of zonality and altitude belts of the vegetation cover. e.g., while classifying steppes for division into areas [1] understood zonal vegetation as plakors phytocenoses homogenous by their composition. He divided the steppe zone into zone-province areas. i.e., the steppe zone was considered here as an independent phenomenon with characteristics of regional heterogeneity of vegetation structure. Dealing with problems of USSR environment zoning [2] understood natural zones as areas of dominant development of the same landscapes. He revealed tundra, forest, forest-steppe, semidesert, desert and subtropical zones. Geographic zonality is main feature of geographical envelop determining the environment diffe-

${ }^{*}$ Corresponding author. 
rentiation of a definite quality, e.g., due to relationship between forests and steps in the south of Central Siberia resulting from shifts of zonal boundaries with spatial alternation of steppe and forest landscapes which formed during last $10 \mathrm{ky}$, modern phytocenotic relationship between forest and grass vegetation forming forest-steppes established. The forest-steppe here, as a zonal unit with equilibrium relationship between annual precipitation sum and evaporation is to be called not transitional one, but axial type of landscape where grass communities of a zonal type are a system of forest and steppe plants species having an appropriate type for this zone spectrum and forming a landscape and ecological unit. Interaction between forest and steppe are determined not only abiotic factors but also is due to biotic reasons: genetic and structural-dynamic features of vegetation types. e.g., forest-steppe biogeocenoses are separated from taiga by subtaiga (subzone). Different communities types are found out in subtaiga. Such communities occur at the boundary of south-taiga subzone of the Angara Region [3]. Forests of taiga-forest type occupy zonal locations and are significantly distributed in subtaiga. Although subtaiga forests have many common features with forest-steppe ones as predominance of meadow-forest mesophytes, the species diversity in forest-steppes is higher, and the role of small-leaved trees as of indicator of forest-steppes zonality is significant. As for placors subtaiga, it is represented by mixed light-coniferous-smallleaved forests. Similar trends are found out under the conditions of well-expressed belts where features of formation of mountain-forest-steppe belt are manifested, this is especial characteristic of Tuva, Tran-Baikal, Mongolia mountains.

In the whole Siberia, there occur in the taiga steppe sites as insulars of different area, often in intermountain troughs, in river valleys, at steep slopes, reaching sometimes tundra boundary. They do not form natural zones from spatial point of view like, e.g., forest-steppe and subtaiga ones [4]. In difference with zonal forest-steppes and zonal (plakor) subtaiga, as well as with forest-steppe belt and with a belt of low-mountain subtaiga, extra-zonal (insular) steppes are a sort of stage of the dynamics of a concrete type of zonal vegetation and of a mountain belt at given climate variability. There is also such a phenomenon as a "tundra-forest" reflecting the ambiguity of tundra development as of zonal vegetation.

\section{Background}

While researching the aspects of relationship of forest and steppe in the Angara Region, G. A. Peshkova [5] noticed the presence of double process: in northern part of the Angara region, the forest gains steppe cenoses, while at the south, territories of steppe communities widen. In her paper "Florogenetic analysis of steppe flora of South Siberia mountains" [6], she presents very curious conclusions about the antiquity of plant species forming steppe communities-mesophytes are the most ancient rather than xerophytes. Consequently, numerous "steppe islands" are temporary, as Ya. P. Prein [7] supposed and V. B. Sochava [8] expressed similar opinion. There are different definitions of communities of transitional natural zones. In particular, the steppe is characterized as a zonal (or a mountain belt under zonality conditions) formation covering large territories as an independent phenomenon. Numerous researchers outline forest-steppes under the conditions of "insular steppes" and call them "insular forest-steppes". They are outlined both under zonality conditions (or altitude zonality), and under the conditions of extrazonality. Is it possible to outline phenomena of quite different natural conditions and to give them equal typological and structural-dynamic importance? Probably, in this case it is necessary to make more concrete a phenomenon with definite set of appropriate characteristics reflecting its manifestation in the space. It is to notice that in botany, geobotany and biogeography, there are other definitions of phytocenoses on contrast natural conditions: "boundary zone”, “contact zone”, “tension zone”, “competition zone”, “ecotones”, "buffer”, "narrow-strip" and "membrane", "boundary", "forest edge" communities, this increases disorder in the phenomenon characteristics, as occurrence of intrazonal environmental heterogeneity is possible, it is observed more often at topological level of its organization. However, from structural-dynamic and genetic points of view, these phenomena are linked and interdependent. Consequently, while determining a phenomenon, it is absolutely necessary to take into account the peculiarities of environmental dynamics and genesis determining typological and dynamical nature of a phenomenon. The problem of relationship and classification of environments contact phytocenoses attracted many vegetation researchers and have a more than secular history [7] [9].

\section{Research Methods and Areas}

The results of the work done are based on more than 1400 geobotanical descriptions with sampling of herbarium material of dominant plants species in the communities. This work is based on materials of research of phytoce- 
noses of the Baikalian Siberia forming under the conditions of extrazonal steppes, in middle part of Tunka and Barguzin Depressions, in South-Western (Pre-Ol'khon) and North-Western (the Rel' River basin), bar vegetation-Yarki Island (Northern edge of Lake Baikal). Model (key) sites were positioned in transitional zones "forest-mountain tundra" (Khamar-Daban and Baikal Ridges), as well as at the territory of the contact of zonal forest-steppe (middle part of the Selenga R. basin). Main methods of our research were as follows: geobotanical survey jointly with field deciphering of large-scale spatial pictures-Landsat 7ETM+, Landsat 2MSS, Landsat 5TM of different survey years (1974-2002); making of schematic maps (scale 1:100,000) of spatial-temporal variability of phytocenoses and soil-geobotanical profiling in environments contact areas for key sites.

\section{Results}

Summarizing the information above, we have to notice that in all the cases presented, key sites of Eastern PreBaikal and of northern margin of Baikal'sky Ridge represent rather well manifested trends of penetration of wood species into sub-goltsy belt, and somewhere into mountain tundra. For Southern Pre-Baikal this is Abies sibirica Ledeb., and for North-Western Pre-Baikal this is mainly Larix dahurica Lawson, rarer Abies sibirica Ledeb. and Pinus sibirica Du Tour. We have to notice that activation of forest expansion onto steppe territory is mainly due to decrease of human impact too. Climate changes also impact the dynamics of vegetation in the forest-steppe zone of this part of Western Trans-Baikal. The spatial changeability of the boundary of zonal forest-steppes as of autonomous vegetation type (native zone) is due just to climate change.

Ecotones. Ecotones are systems which are subject of special research. As there is no clear definition of them, the notion "ecotones" is used for any systems of transitional type, both interzonal and intrazonal heterogeneity of any environment. The term "ecotone" was used in the papers of English and American researchers [10] as characteristics of transition between two plants associations. The role of ecotones as of buffer communities in spatial vegetation structure was taken into account in the research by V. B. Sochava [8]. He affirmed that in the areas where an ecotone occurs, there is an impression of diffuseness of boundaries between the communities, and presentation of an ecotone on the maps eliminates in some way the establishment of boundaries, but simultaneously, this generates a series of new questions concerning presentation of phytocenoses genesis and structure. Presentation of ecotones emphasize the continuity of vegetation cover at transitional zones and allows at the same time to establish boundaries between different structures of zonal vegetation while classifying them. Other researchers recognize ecotones as well [11] considering them as an important element of botanical geography. Ecotones have a specific structure reflecting a large set of characteristics of a phenomenon with very unexpressed links between components of biotic and abiotic environmental factors. They have particular properties and structure different from zonal natural systems [12]. Ecotones represent a result of formation of continuity of biocenotic cover playing the role of membranes, buffer and refugia functions. Structural-functional organization of ecotones systems risen during systems evolution is of great importance for research of global environmental changes. Main tasks for research of ecotones systems nowadays are: typology, zoning and mapping with revealing of processes of ecotone transformation of biocenotic cover and of dynamics of biosphere processes. Ecotone is understood as a topographic transitional zone of differences of vegetation cover at the boundary of forest and steppe zones (as well as at vertical zonality) as representation of structural and cenotic peculiarities of vegetation in any zone (or belt). Also, we have to notice papers of such researchers in this field [13]-[20]. The importance of this problem is evident in modern ecology, biogeography, phytocenology and plants geography.

However, the notion "ecotone" is used as well for a transitional belt between elementary territorial units (micro-groups, phytocenosis). Besides, this notion is used for transitional belts between ecosystems. One distinguish as well ecotones of first and second orders. Hence, an "ecotone" is a transitional state of communities of environments contact of any size and territorial location. In this case, outline of ecotones is not due to any definite characteristics of environment, i.e., this notion characterize both interzonal, subzonal, intrazonal heterogeneity of vegetation structures and ones between altitude belts and out of zones. There is a question if we have right to use the same notion for characteristics of phytocenoses at the contact of different environments. e.g., is it possible to outline forest-steppes as an ecotone under the condition of steppes extrazonality and at absence of zonal forest-steppes, as well as to characterize insular steppes and forest edge as "ecotones"? If this is possible, so, the attempts to reveal the dynamics and to determine the direction of natural processes development via the phytocenoses structure are very conventional. 
We believe that total consideration of historic and genetic peculiarities of formation of vegetation in a concrete region, of modern physico-geographic conditions determining the zonality, the subzonality, the altitude belts or extrazonality of definite environments generating formation of concrete vegetation: tundra, forest-tundra, taiga (subtaiga), steppe, forest-steppe, extrazonal steppe (steppe islands) is necessary. In this case, vegetation typification and classification will be more impartial? And it will be unnecessary to call the communities of different environments by the same notion. We have to make more concrete the informational value of the word "ecotone" as of a notion of a phytocenoses of an environment or to offer an additional system of classification of vegetation at different environments contact. At the example of the regions of the Baikal Siberia of the key sites we are going to consider modern trends of ecotones formation among the vegetation of different environments:

\subsection{Examples of Ecotones}

Key site-the Osinovka river basin of Pre-Baikal. This is the territory of Baikal Biosphere Natural Reserve. We used information for comparative characteristics of spatial variations of forest upper boundary with time from studies by G.I. Galaziy [21]. They represent the peculiarities of structural and dynamic organization of wood vegetation at the vertical boundary of its distribution in the southern part of Khamar-Daban Ridge (upper reach of the Langatuy R.) in $50 \mathrm{~km}$ from the point of our studies - upper reaches of the Osinovka River. The absolute height of our model territory is $1935 \mathrm{~m}$ asl. The absolute height of mountains where G.I. Galaziy [21] performed his studies is $1700 \mathrm{~m}$ asl (Khamar-Daban Ridge, Langatuy Gate). As data of our studies are obtained in 2008, and materials used in the paper by G.I. Galaziy [21] are dated by 1951, the period for comparison of spatial variability of the forest upper boundary in the middle part of Khamar-Daban Ridge is 57 years. It is to notice that materials obtained by G.I. Galaziy in 1951 and data of our studies are collected for the habitats of similar orography - slopes of northern expositions. This allows perform a rather correct comparative analysis of data obtained.

Common characteristics of the vegetation in the studied area-upper reaches of the Osinovka River. The studied area belongs to the territory of State Forest Resources, this is water protection zone of Lake Baikal basin. According to correlative ecological-phytocenotic map [22], the plant systems of the territory are represented by mid-mountain, mainly fir (Abies sibirica Ledeb.) — cedar (Pinus sibirica Du Tour) blueberry (Vaccinium myrtillus L.) — short-grasses-green mosses, cedar (Pinus sibirica Du Tour) and cedar (Pinus sibirica)—spruce (Picea obovata Ledeb.) undershrub-green mosses forests and by their birch (Betula rotundifolia Spach.) —aspen (Populus tremula L.) restoring series of moderately cold and humid habitats. In consistence with the map of "Zones and Zonality Types in Russia and in Adjacent Countries", the vegetation of this region is related to boreal (taiga) Tuva-Southern Baikal zonality type, Khamar-Daban subbelt of taiga (Abies sibirica Ledeb., Pinus sibirica Du Tour) forests of lower and middle parts of the slopes transforming into subgoltsy belt of Pinus pumila (Pallas) Regel and of goltsy represented by mountain tundra with synusias of Pinus pumila (Pallas) Regel and sedge (Carex sp.) groups in combinations with stony placers. According to "Map of Vegetation of the South of East Siberia” [23], plant communities of the studied area are related to taiga (boreal) vegetation of Ural-Siberian phratry of formations, to South-Siberian formations of mountain taiga dark-coniferous forests. In tail areas and in the lower parts of the slopes of Northern and North-western exposition there form forests of cedar with admixture Picea obovata Ledeb , Larix sibirica Ledeb., Abies sibirica Ledeb., ones of ledum (Ledum palustre L.) —blueberry (Vaccinium myrtillus L)-cowberry (Vaccinium vitis-idaea L.) - green mosses in combination with bergenia (Bergenia crassifolia (L.) Tritsch) cedar forests (Pinus sibirica Du Tour). For the valley of lower stream of the Osinovka River (it is the territory of Baikalian Biosphere Natural Reserve) systems of fir (Abies sibirica Ledeb.) - poplar (Populus suaveolens Fischer) and spruce (Picea obovata Ledeb.)-fir (Abies sibirica Ledeb.) tall grasses forests are characteristic. At middle parts of the slopes of Northern and North-Western expositions, there are cedar (Pinus sibirica Du Tour.)-fir (Abies sibirica Ledeb.) undershrub-grass green moss forests. The vegetation of upper parts of the slopes are represented by alpine-like and subalpine-like meadow groups in combination with bushes-(Betula rotundifolia Spach, Salix alba L.) and with Pinus pumila (Pallas) Regel related to South Siberia formations, Altay-Tyan'-Shan' phratry of alpine formations of goltsy vegetation. Subgoltsy belt is characterized by bushes of mountain pine in combination with mountain tundras related, according to the map of vegetation [23], to Baikal-Dzhugdzhur formations of Berengy phratry of formations. Some peculiarities of spatial and cenotic organization of the vegetation in the studied area and its environment were presented in the papers of numerous researchers. It is to notice especially that replacement of wood species (Kha- 
mar-Daban) during the Holocene occurred multidirectionally, from decrease of spruce (Picea obovata Ledeb.) and fir (Abies sibirica Ledeb.) components and decrease of cedar fraction (Pinus sibirica Du Tour) from the beginning of Mid-Holocene to Late Holocene due to decrease of total humidity and increase of continental character of the climate. During last stages of Late Holocene, increase of areas occupied by second growth began to show. At present, active renewal of fir (Abies sibirica Ledeb.) and cedar (Pinus sibirica Du Tour) is observed. Probably, there is here overlap of processes of natural replacement of dominant species in forest communities and a relative increase of atmospheric humidity.

Current structure of the plant communities of key site - the Osinovka river basin: Studies performed at the key site by method of field geobotanical survey allowed to reveal the modern structure of plant communities of transition belt along the profile "dense timber stand-subgoltsy belt-mountain tundra"(middle part of Khamar-Daban Ridge, upstream of the Osinovka River, Baikal Biosphere Natural Reserve). Here are geobotanical descriptions upword the profile.

Description No. 1 (height of $1500 \mathrm{~m}$ asl)—boundary of transition of dense timber stand to bushes of mountain pine together with fir young growth:

Cedar (Pinus sibirica Du Tour)-fir (Abies sibirica Ledeb.) with Betula fruticosa Pallas with young growth (Abies sibirica Ledeb.) and clumps of Pinus pumila (Pallas) Regel forest of the upper part of the slope of northern exposition. The second layer is dominated by Abies sibirica Ledeb. with rare Pinus sibirica Du Tour and sporadically—with Betula fruticosa Pallas. Brush layer consists of Rhododendron aureum Georgi—synusially, Ledum palustre L.—synusially, Juniperus sibirica Burgsd.—scarcely, and underbrush are presented largely by Vaccinium myrtillus L-everywhere, there is also Empetrum nigrum L.-synusially. In the depression there is megasea-synusially, on the knolls within the slope the clumps of Athyrium distentifolium Tausch ex Opiz, Oreopteris limbosperma (All.) Holub., Dryopteris sp., Dryopteris filix-max (L.) Schott and Oreopteris connectilis (Michx.) Watt. are formed-synusially. Pulsatilla multifida (G. Pritzel) Juz. is widely represented. Among mosses, Dicranum polysetum Sw. and Aulacomnium acuminatum (Lindb. et Arn.) Par. are characteristic.

Description No. 2 (height of $1650 \mathrm{~m}$ asl) —belt of Pinus pumila (Pallas) Regel, dense timber stand is absent:

Young growth of Abies sibirica Ledeb. (age from 5 to 20 years) within the belt (1500 - $1750 \mathrm{~m}$ asl) of Pinus pumila (Pallas) Regel together with Salix lanata L. Species composition of the community is formed by Rhododendron aureum Georgi-synusially, Vaccinium myrtillus L.—synusially, Empetrum nigrum L.—scarcely, Bergenia crassifolia L.- scarcely, ferns are represented by Athyrium distentifolium Tausch ex Opiz and Dryopteris filix-max (L.) Schott-synusially, Huperzia arctica (Tolm.) Sipliv. and Pulsatilla multifida (G. Pritzel) Juz. occurs everywhere. We have to notice here that among synusiae of Pinus pumila (Pallas) Regel, underbrushes and Bergenia crassifolia L., young growth of Abies sibirica Ledeb. are more developed in difference with its single specimens among Pinus pumila (Pallas) Regel and bushes of Polypodiaphyta ferns.

Description No. 3-graded surface of the top of mountain Osinovka (absolute height is $1935 \mathrm{~m}$ asl)-there synusially situated single brushes of Pinus pumila (Pallas) Regel, clumps of Vaccinium vitis-idaea L., Empetrum nigrum L., Mosses sp. and Carex sp. around small hollows.

During last decades, trends of advance of Abies sibirica Ledeb. out of canopy of timber stands into the belt of Pinus pumila (Pallas) Regel up to mountain tundras arose everywhere in the ecotone "forest-mountain tundra". In average this is 200 - 250 meters, maximally-up to $500 \mathrm{~m}$ in linear distance from dense timber stand.

Key site - the Gramna River basin (North-Western Pre-Baikal). The key site-surrounding area of a golets with the absolute height of $-1834.2 \mathrm{~m}$ asl is situated in the interfluve of upper reaches of the Gramna and Goudzhekit RR. At the northern margin of Baikal'sky Ridge (North-Western Pre-Baikal, Davan pass). Before construction of the Baikal-Amur Railway, the vegetation of the North Pre-Baikal Region was impacted only by natural factors including pyrogenous one. During the railway construction, the vegetation of intermountain notches and mountain feet was actively exploited (mainly by timber stands cutting). There were sometimes fires, however, the vegetation of near-top parts of mountain slopes and of sub-golets belt is kept in its natural state.

Common characteristics of regional vegetation in the Gramna River basin. According to the map of vegetation of the south of East Siberia [23], plant communities of the studied area are related to taiga (boreal) vegetation of Ural-Siberian phratry of formations, to Southern Siberia formations of mountain taiga dark-coniferous (Pinus sbirica Du Tour, Abies sibirica Ledeb.) forests, to cedar underbrush (Betula rotundifolia Spach., Rhododendron aureum Georgi) moss-lichen light forests (often together with underbrush bushes) in combination with bushes of Pinus pumila (Pallas) Regel and sparse Larix dahurica Lawson, birch (Betula lanata (Regel) V. Vassil.) of Baikal-Dzhugdzhur formation (Beringia phratry of formations) of mountain taiga and light forests to- 
gether with mountain tundras represented by non-close groups of Saussurea pseudosquarrosa M. Pop. Et Lipsch. among stony deposits. According to the map of zones and types of zonality of vegetation in Russia and in adjacent countries, the studied area is related to Pre-Baikalian goltsy—tundra-elfin woodlight forest—-taiga type of zonality of vegetation applicable to the Baikal Region.

According to correlative ecological-phytocenotic map [22], plant communities of the territory are represented mainly by a system of mid-mountain fir (Abies sibirica Ledeb.)-cedar (Pinus sibirica Du Tour) blueberry (Vaccinium myrtillus L.) —short grasses—green mosses, cedar (Pinus sibirica Du Tour) and cedar (Pinus sibirica Du Tour)-spruce (Picea obovata Ledeb.) underbrush-green mosses forests and by their pine (Pinus sylvestris L.)larch (Larix dahurica Lawson) and birch (Betula sp.)-aspen (Populus tremula L.) renewed series of humid habitats.

Current structure of the key site-upstream of the Gramna River: We present main characteristics of communities revealed in our studies, common characteristics of modern structure of communities in the studied area. Practically everywhere there is a layer structure of forest communities where the I layer consists of Abies sibirica Ledeb., Pinus sibirica Du Tour, Larix dahurica Lawson, Picea obovata Ledeb.; II—of Pinus sibirica Du Tour, Abies sibirica Ledeb., Picea obovata Ledeb., Larix dahurica Lawson (often Betula lanata (Regel) V. Vassil.). Undergrowth consists of the Duschekia fruticosa (Rupr.) Pouzar and Betula rotundifolia Spach.at all. The young growth is dominated by Abies sibirica Ledeb. and Larix dahurica Lawson in different quantitative ratios (variations) depending on their position-slope exposition. Abies sibirica Ledeb. and Larix dahurica Lawson (rarely Pinus sibirica Du Tour) of reproductive age reach and enter the subgoltsy belt. Subgoltsy belt is dominated by Pinus pumila (Pallas) Regel together with Betula lanata (Regel) V. Vassil., Rhododendron aureum Georgi, Bergenia crassifolia L. and Vaccinium vitis-idaea L. There are characteristic Dicranum polysetum Sw., Hylocomium splendens (Hedw.) BSG, Aulacomnium palustre (Hedw.) Schwaegr. Which are edificators of ground cover of dark-coniferous zonal taiga. They form clumps between stones (boulder pavements) everywhere. There are some species of Lichens of the genera Cladonia and Cetraria everywhere.

There is a peculiarity of spatial organization of vegetation in the studied area: availability of young growth of Abies sibirica Ledeb. and Larix dahurica Lawson (aged from 2 - 3 to 25 years) in the subgoltsy belt. There are single small trees of Larix dahurica Lawson and Abies sibirica Ledeb. Out of the subgoltsy belt, mainly on "shadowed" slopes, as well as in stony tundra.

Key site-basin of the Selenga River (south-western Trans-Baikalia). According to botanical-geographic zoning, it belongs to the Central Asian (Dauro-Mongolian) sub-region of the steppe region of Eurasia. The vegetation of the region is attributed to the Hangai-Daurian mountain forest province and the subprovince of Orkhon-Lower Selenga forest-steppes [24]. Its composition and structure are described in detail in several publications. It basically consists of taiga (boreal) vegetation of the Ural-Siberian phratry that comprises formations of mountain taiga pine and larch-pine forests of herb-dwarf shrub type in combination with steppificated herbshrub pine forests and small bunch grass steppes belonging to Southern Siberian formations of mixed herb-grass and grass steppes [23]. According to the map of vegetation zoning in Russia and neighboring countries, plant communities of this territory belong to the boreal (taiga) western Baikal forest-steppe (Kyakhta) type of vegetation belts. Steppe communities composed by Elytrigia repens and Iris biglumis are fairly widespread in the Selenga forest-steppe. There also are synusiae dominated by Caragana spinosa and halophyte communities with Kalidium foliatum and Nitraria sibirica, and some communities are dominated by Stipa pennata, the species common in the Khakass-Minusinsk steppes and Angara region.

Current structure of the key site-basin of Selenga River. The zonal forest-steppe is represented by communities formed within limited areas on slopes of different aspects, which have features characteristic of herbaceous light conifer forests and of zonal steppe communities. The structure of steppificated herbaceous forests shows a trend toward an increase in the amount of undergrowth since the 1970s. The dynamics of forest regeneration processes under conditions of zonal forest-steppes reflect stratification of the ground vegetation layer and increasing abundance of undergrowth, which is indicative of the tendency toward progressive natural afforestation of open steppe areas. Against the background of recent climate dynamics and general reduction of grazing load during the past decades, these processes "level off" the boundary between forest and steppe communities in key site. The abundance of tree undergrowth beyond the forest canopy and its occurrence in steppe communities provide evidence for the increasing role of forest component in the structure of vegetation, which in the zonal forest-steppe may be regarded as a natural process of plant cover formation in a given period of time. The main probable factor that can restrain natural afforestation of steppe areas within the zonal forest steppe is intensification of grazing against the background of sharp climate changes that may lead to fire hazard situations in the re- 
gion at all.

Paragenese. The paragenese is characteristic for different environments [25]-[28]. e.g., paragenese of modern exogenous processes is understood as combination of a series of jointly occurring related, adjacent or associated close processes. At the same time, the change of processes in lateral direction is characterized as a succession. The authors [28] believe that geochemical specialization of geological system and of forming soils is a base where concrete biota of a concrete territory generates. There is a genetic relationship of regional and local paragons resulting in formation of geochemical specific features of soils favoring formation of concrete biogeocenoses. L. A. Yevdokimov [29] dealt in his research with paragenese of flora and vegetation. The theory of flora and vegetation paragenese is one of least studied levels of vegetation cover organization. At the junction of botanic geography and phytocenology, the theory of flora and vegetation paragenese allows to solve a series of tasks from systematics to relationship between classification, division into areas and mapping of vegetation cover via research of the regularities of historic and geographical development of vegetation. Research of flora and vegetation paragenese at floristic level are systematic ones. We have to notice here as well postulates about difficulties of use of such a notion as paragenesis in the characteristics of structural-dynamic organization of vegetation cover [30]. To determine paragenesis, we have to observe a series of criteria such as common origin, spatial vicinity or compatibility, different quality or the same level of organisation of compounds of vegetation paragenesis. These postulates are quite evident and, in our opinion, the following postulate is very important: dynamical processes of different level are manifested at different territories, and they cannot be considered completely without specifics of territorial organization of vegetation. Therefore, e.g., the dynamics of forests, as well as their genesis, can be considered only jointly with other communities types (meadow, steppe, swamp) at a concrete territory and in a concrete zone simultaneously. We attempted to classify phytocenoses under the condition of contact of light-coniferous taiga and extrazonal steppes of some sites in the Baikal Region.

\subsection{Examples of Paragenese}

Key site-central part of the Western Pre-Baikal. As a result of the research performed, new data characterizing the peculiarities of phytocenoses development formed under different physical and geographical conditions were obtained. Extra-zonal effects in the state of vegetation cover are characteristic for the vegetation of model territories on the key site in taiga zone, in the central part of Lake Baikal Western coast (Pre-Ol'khon). On large-scale geobotanic maps of two model territories-Talovka River basin (southern part of Pre-Ol'khon) and Maloye Morye coast (Central Pre-Ol'khon) detailed structural and dynamic parameters of phytocenoses in the contact area between taiga and extra-zonal steppes are presented.

Current structure of the plant communities of the Key Site (two model territory). Main characteristics of phytocenoses in the contact area between taiga and extra zonal steppes are:

One model territory - the vegetation of a model territory Talovka River basin (southern part of Pre-Baikal) is characterized by different contact of forests with green mosses containing also Larix sibirica, Duschekia fruticosa, Rhododendron dauricum with external cover containing Rhytidium rugosum, Drepanocladus uncinatus, Dicranum polisetum, Ptilium crista-castrensis, Polytrichum juniperinum, Mnium cuspidatum, Abietinella abietina and forests containing pines Pinus sylvestris, sparse grasses, as well as Rhododendron dauricum with Iris ruthenica and Pyrola rotundifolia, Vaccinium vitis-idaea with areas containing extra zonal steppe communities where Poa botryoides, Agropyron cristatum, Veronica incana, Galium verum, Potentilla tanacetifolia, etc. dominate. Grass communities here are synusial and are due mainly to such violation as fires and forest cutting. Species composition of such communities includes both steppe and meadow-forest (taiga), meadow plants species. Everywhere among steppe communities there are beds and regrowth of Pinus sylvestris, sometimes of Larix sibirica.

Second model territory - as for the vegetation of another model territory-Maloye Morye coast (central part of Pre-Baikal), here in all the forest larch dominates with underbrush consisting of Rhododendron dauricum, mosses are abundant in the soil cover, these are Rhytidium rugosum, Drepanocladus unicinatus, Dicranium polisetum, Climacium dendroides, Hylocomium splendens, Pleurozium schreberii, Rhytidiadelphus triquetrus, etc. We have to notice that Pinus sibirica aged from 2 to 28 occurs among larch forests of this model territory, and mosses are edificators of soil cover of polydominant light- and dark-coniferous forests (taiga) which are typical for the whole Pre-Baikal. Steppe communities occupy rather large territories where the following species dominate: Poa botryoides, Festuca lenensis, Chamaerhodos altaica, Potentilla tanacetifolia, Astragalus versicolor, 
Scabiosa comosa, Artemisia frigida, etc. Among these steppe communities, larch Larix sibirica aged from 2 to 40 is developed, there are some trees aged up to 150. Perennial monitoring (during 21 years) of the dynamics of vegetation formation on these model territories allowed to reveal and to state particular type of phytocenosestaiga-steppe ones. These communities are a dynamic stage in the development of forest in Western Pre-Baikal taiga zone. The development of vegetation in this part of Lake Baikal basin is to be characterized as an example of vegetation paragenese in taiga zone as it is understood nowadays. Concerning the vegetation on the second key site-contact area of steppes and zonal forest-steppes, the development of transitional communities is typical here. They consist of Stipa krylovii, Artemisia frigida, Potentilla acaulis, Festuca lenensis, Poa botryoides, etc. In the forest communities with soil cover consisting of forest-steppe plants species, undergrowth and young growth are higher than forest canopy. Mosses are not found.

Key site-the Tunka Valley (the south-western Pre-Baikal). This area is not included in any region, subregion, or province of steppes and forest-steppes according to botanical-geographic zoning [24] [31] but lies at the junction of extrazonal steppes of lowland (depression type) steppes and polydominant dark and light conifer taiga forests. Characteristic of the Tunka Valley are mountain taiga forests classified with southern Siberian formations of the Ural-Siberian phratry [23]. The right wall of the valley is covered by wild rosemary-cowberry-moss Siberian stone pine forests with spruce and larch in combination with Siberian stone pine forests of rhododendron-bilberry-cowberry-moss and bergenia types; the left wall, by herb-dwarf shrub pine and larchpine forests. On the bottom, there are herbaceous larch, pine-larch, and pine forests alternating with steppificated larch stands (in the upper reaches); pine forests (in the middle and lower reaches); and steppe areas. This site has long been exposed to anthropogenic impact, which has contributed in part to steppification processes and consequent formation of lowland (depression type) steppes) with steppe communities alternating with fragments of steppificated forests, which are oriented in the forest belt depending on terrain exposure.

Current structure of plant communities of the Key Site. The present day vegetation of the key site basically consists of steppificated pine forests in combination with steppe communities, and almost all of the latter contain abundant pine undergrowth (in most cases, of 10 to 15 year old trees). It should be noted that a considerable part of the valley was long used for livestock grazing (and often exposed to controlled fires) or was plowed in the early 1950s, which interfered with the course of natural vegetation development, mainly as concerns forest communities. The presence of even aged tree stands confirms this conclusion. The ground vegetation layer has long been dominated by species of the family Poaceae. The present day spatial pattern of vegetation is accounted for by the impact of anthropogenic factors (livestock grazing, plowing, tree cutting, fires) against the background of climate dynamics (in particular, as concerns the distribution of annual average precipitation by seasons). A comparative analysis of changes in the relative areas of forest and steppe communities (based on field interpretation of satellite images made in different years) has revealed a tendency toward natural afforestation of steppe areas during the past 25 - 40 years. Gradual forest expansion to extra zonal (depression type) steppes is a response to changes in environmental conditions during the past few decades. In taiga forests of the southwestern Baikal region, these processes should be regarded as climatogenic succession within the boundaries of zonal vegetation. Soil-geobotanical profiling has revealed no direct relationship between the structure of plant communities and soil types. Steppe communities in site are extra zonal, while the composition of soils is characteristic of zonal light conifer forests. According to the most recent classification the soils of this region are cryoarid (azonal) soils, which are reflected in the formation of steppificated forests in combination with steppe communities. Forest and steppe communities grow on the same soil types.

Key site-north-western of the Pre-Baikal. By botanical-geographic subdivision of Central Asia (Dauria-Mongolia) sub-area of Eurasian steppe area [24] [31], the steppes of the research area (key site- the Rel' R. basin) are not related to any sub-area or sub-province of forest-steppes and steppes. Steppes territories of the key site at North-Western coast of Lake Baikal are included in zonal taiga of Northern Pre-Baikal, and are characterized at present as "insular steppes". The base of communities on the territory of contact (key site) of extrazonal steppes and polydominant dark-coniferous-light-coniferous taigas are larch-ledum, cowberry-green moss forests at the slopes of north-western expositions. The timber stand is multilevel with larch undergrowth everywhere. A particular feature of these phytocenoses composition is the presence of Pinus sibirica Do Tour (Siberian pine) aged 18 - 25 years in the second growth. In the soil cover there are such plants species as Potentilla flavescens (Zucc.) Juz., Artemisia gmelinii Web. ex Stechm., Galium boreale L., Festuca lenensis Drobov, locoweeds and sedges. At the slopes of southern expositions there form larch stands with features of grassland steppe with presence of Spiraea media Franz Schmidt, Ledum dauricum L., as well as mosses synusiae characteristic for 
dark-coniferous taiga. Timber stand is mainly multilevel with undergrowth of larch and seldom of cedar. Grass (steppe) communities are mainly developed along interslope valleys, aprons of slopes of different expositions and are represented by such plants species as Artemisia frigida Willd., Artemisia laciniata Willd., Potentilla acaulis L., Carex duriuscula C.A.Mey and Carex pedifoformis C.A. Meyer, Aster serpentimontanus Tamamsch, Allium tenuissimum L., Veronica incana L., etc. Among such communities there is larch undergrowth spread often out the canopy, especially at shadowed slopes.

Steppe communities having extra zonal nature served for a long time (especially in 1960-1980ies) as pastures. However, during last decades, the anthropogenic impact abruptly decreased, and in parallel with increase of annual precipitation (as well as their re-distribution by vegetation periods towards late summer and autumn) favored formation of communities with trees species. Structural changes in the composition of communities in the research area are suggested by increase of dark-coniferous species (cedar) in light-coniferous taiga together with forests ingress into steppe sites during last decades everywhere. The character of modern state of communities forming under the conditions of contact of forests and extra zonal steppes in the research area reflects paragenese in the formation of regional vegetation, this was found out before as well in other Pre-Baikalian regions.

Field deciphering of spatial pictures taken in different years allowed as well to reveal modern trends of formation of vegetation at the key site (and of the whole north-western coast of Lake Baikal) with gradual afforestation of steppe (extrazonal) territories everywhere. We have to notice here that further climate change in the region, mainly concerning precipitation, will favor the development of polydominant taiga instead of steppes, probably with xerophyte-petrophyte vegetation groups at steep eroded slopes at south-western exposition and stony ridges. Such processes at this site can be restrained by probable increase of anthropogenic impact—pasture, haying, burning and cutting of timber stand at the contact of forests and extrazonal steppe communities.

Key site-northern Pre-Baikal. Some features of natural conditions of formation and vegetation at this key site are presented by several researchers [32] [33] showing regional and local peculiarities of phytocenoses adapted to limnological conditions of North Baikal. In the near-coastal area of Lake Baikal, a complicated system of local circulation forms, it creates a unique wind regime different from one of open lake and influences considerably onto coastal climate. The North-Eastern coast (our research area) considerably differs by thermal regime values from other coastal areas of Lake Baikal. It is characterized by lower air temperatures during the whole year, low sums of positive temperatures, comparatively short no-frost periods. Conditions for plants growth here are less favorable than in other areas of Lake Baikal coasts.

The most considerable role in transformation of Yarki Island bar belongs to eolian processes which, from historical point of view, took place together with tectonic shifts and, probably, glacial-isostatic movements. The dynamics of Yarki Island bar is mainly due to hydrothermal processes depending on the level of lake oscillation complicated by up thrust of Irkutsk Hydroelectric Power Plant. At the level increase the "beaches" submerge, the coast is subjected to an intensive abrasion. At maximal abrasion values, a part of the bar, i.e., Yarki Island itself, form steep bumps. Eolian processes play a significant role in Yarki island re-formation creating new shapes impacted by northern and southern winds, where sand transfer by northern winds is more significant. Under the impact of ice drifts in winter, peat deposits thrust onto stony beaches and form peat swells. At eolian microforms, phytogenic dumps and spits of different sizes occur mostly. Deflation microforms of bar relief form after numerous storms as well. The Yarki bar had initially an equal shape with the same heath populated later by Pinus pumila (Pallas) Regel, resulting in increase of bar height due to exposure accumulation.

Common characteristics of key site plant communities. Main vegetation of sandy relief of the key site consists of dwarf birch with inclusion of Pinus pumila (Pallas) Regel, ledum-leatherleaf-sphagnum, ledum-sphagnum, ledum-cowberry-sphagnum plants groups (in particular, suburbs of Nizhneangarsk settle., banks of the Kichera R.). Here mountain pine formation dominates; it forms together with dwarf birches. Under the canopy of mountain pine and dwarf birches Ledum palustre L. grow, in the soil cover there are mosses-Pleurozium schreberi (Brid.) Mitt., Aulacomnium palustre (Hedw.) Schwaegr., Polytrichum affine Funck, Polytrichum strictum Sm.

Current structure of plant communities. Phytocenoses of the bar itself at Yarki Island are formed by Pinus pumila (Pallas) Regel, Betula platyphylla Sukachev and Betula pubescens Ehrh. Sometimes undergrowth of Daurian larch occurs (Larix dahurica) jointly with Sorbaria pallasii (G. Don fil.) Pojark. and Padus avium Miller. Soil cover of open territories consists of Elymus sibiricus L., Festuca rubra L. s. str., Astragalus sericeocanus Gontsch., Carex sabulosa Turcz. ex Kunth, Equisetum arvense L., Calamagrostis epigeios (L.) Roth. Under the canopy of Pinus pumila (Pallas) Regel. there are widely distributed Empetrum nigrum L., Linnea boreale L., Arctostaphylos uva-ursi (L.) Sprengel, Ledum palustre L. s. str., Vaccinium vitis-idaea L. s.str., Vaccinium uli- 
ginosum L. s.str. And synusially-Carex rhynchophysa C.A. Meyer and Carex globularis L. There are single trees of cedar (Pinus sibirica Du Tour) with undergrowth of Larix daurica. Especially we have to pay attention here to rather large growth of Achnatherum splendens (Trin.) Nevski and Festuca rubra L. s.str with inclusions of the Iris laevigata Fischer et Meyer.

The vegetation of sandy relief of Lake Baikal coastal line, especially of its eastern coast, where there are in the community structure Pinus pumila (Pallas) Regel with Empetrum nigrum L., Ledum palustre L. s. str., Vaccinium uliginosum L. s.str., as well as Pinus sibirica Du Tour, Larix daurica and elfin wood form of Abies sibirica Ledeb. It is characterized as a "false subgoltsy" belt [34] in the spatial structure of the pre-coast vegetation. This opinion is kept until nowadays. However, we have to notice here that any environmental zone (mountain belt) has always definite natural and climatic characteristics of biotops. And when there are among phytocenoses plant species typical for different characteristics of vegetation (natural zones, mountain belts), and in our case, there are in the communities plants of zonal dark-coniferous and mountain taiga, subgoltsy belt, mountain tundra, psammophytic and halophytic steppes, meadows and lowland moors, it is probably not correct to determine these phytocenoses as abelt, even "false subgoltsy" one. Probably, in this case as well there is paragenese in formation of research area vegetation—at Yarki Island bar, just at Northern Pre-Baikal.

\section{Discussions}

It results from presented geobotanical descriptions at the key site-upstream of the Osinovka R. (Southern Pre-Baikal) that during last decades, there are trends to advance of a wood species-Siberian fir out of canopy of timber stand into the belt of mountain pine up to mountain tundras. In average this is $200-250 \mathrm{~m}$ (and directly - up to $500 \mathrm{~m}$ ), this is a rather evident confirmation of change in upper forest boundary. We have to notice here that according to data by G.I. Galaziy [21], the manifestation of upper boundary of wood vegetation is found at the height of $1600 \mathrm{~m}$ asl. This is ca. $50 \mathrm{~km}$ south-westward of our model site-upstream of the Osinovka R. In the timber stand at the upper forest boundary, there are all forest renewal stages: coming-up, young growth, polewood and young Abies sibirica Ledeb. on the second layer. Regrowth of Abies sibirica Ledeb. out of timber stand boundary suggest favorable conditions during last years resulting in abundant seeds crop. In general, the advance of young growth above the boundary of dense timber stand is a rather slow process from time viewpoint, but under favorable circumstances, one can notice a gradual advance of Abies sibirica Ledeb. Into sub-goltsy belt, this was just found out for middle part of Khamar-Daban Ridge-our key site. From our viewpoint, this information can be a sort of evidence of occurring shift of upper forest boundary which is probably characteristic for the whole mountain system of Khamar-Daban but with some corrections according to environmental conditions, as Khamar-Daban Ridge forms a rather extensive system of Southern Pre-Baikal mountains. Due to this fact, additional studies of the upper forest boundary in other areas of Southern Pre-Baikal ridges are necessary. As rather detailed data obtained 57 years ago [21] for concrete sites-upstream of the Langatuy R., Kamarsky Ridzhe and upstream of the Bystraya R. (western branches of Khamar-Daban Ridge) are available, it is quite probably to obtain some additional information concerning the dynamics of upper forest boundary for the whole region. During last decades, some tendencies of advance of Abies sibirica Ledeb. out of timber stand canopy into the belt of Pinus pumila (Pallas) Regel up to mountain tundra in the ecotone "forestmountain tundra” of the Mishikha River basin (middle part of the eastern coast of Lake Baikal) arose as well. Peak of forest renewal occurred in 1989-1995 and, probably, was due to a high productivity of seeds of fir timber stands in the end of 1980ies and to warm winters of the first half of 1990ies resulting into formation of favorable climate-edaphic conditions of penetration of wood species into sub-goltsy belt and mountain tundra. At the key site- upstream of the Gramna River, there is advance of wood species into sub-goltsy belt and mountain tundra, but they depend significantly on heights, exposition and tilt of the slopes, sites of growing of concrete communities. In this case, forest boundary is observed especially distinctly along the slopes of southern expositions, while at "shadowed" slopes, the boundary between forest and mountain tundra is less manifested and is interrupted somewhere. Often wood species penetrate along intermountain crests deeply (often up to hundreds of meters) into sub-goltsy belt. The presence of a large amount of well-developed streaks and combs in the mountain system structure favors as well formation of interrupted, with significant heights drops, boundary between forest and sub-goltsy belt (often tundra as well); this is manifested by presence of young growth of wood species both in sub-goltsy belt and in stony tundra.

We have also to notice that similar trends in formation of ecotones "forest-mountain tundra" were found out 
before as well for Primorsky Ridge (South-Western Pribaikalyay), where Pinus sibirica Du Tour penetrates actively into sub-goltsy belt with single occurrence of trees into mountain tundra (environment of Sarminsky golets, upstream of the Sarma River). Probably, we have to relate such processes to changes in hydrological and temperature regimes of vegetation periods of last decades resulting in formation of more favorable conditions for the growth of wood species in high mountains of the Baikal Siberia. It is appropriate to tell due to this fact that similar spatio-temporal variations in the structure of plant communities in ecotones "forest-mountain tundra" are appropriate as well for some territories of Ural mountain system.

We suppose that in this case there is intrazonal paragenese (just inside of natural zones); it corresponds to some degree to statements of some researchers. Their opinions are presented in the introduction of this very article. However, geological or geochemical paragenese or soils paragenesis are phenomena of different nature, and vegetation is a more dynamic compound of ecosystems. In our opinion, the vegetation paragenese in the environments contact area, in particular, one of Baikal Siberia, is to be considered as manifestation of environmental conditions (relief structure, temperature and humidity dynamics) on a concrete territory. It can be presented at local (topological), regional (including basins of large water bodies and rivers) and continental levels of environment. If we consider vegetation paragenese as a polyzonality phenomenon, we have to modify the sense of the notion "native zone". Maybe, vegetation paragenese in the environments contact area is a manifestation of ecotones of different size as they are understood nowadays? However, paragenese phenomenon is characteristic for intrazonal environments rather than for interzonal ones. We believe that paragenese both includes and reflects the specifics of condition of vegetation formation conditions on the background of climate dynamics and changeability. The vegetation in the environments contact areas is just the most evident paragenese manifestation. Phytocenoses diversity of first of all typological and classification importance is due just to paragenese. This phenomenon can serve as a base in the studies of plants species biology, of phytocenoses ecology, and of genesis of the whole environment. This article represents mainly a preliminary analysis of the problem stated. This is an attempt to present the peculiarities of tendency of phytocenoses development under contrasting environmental conditions.

\section{Conclusions}

The use of any definition must be confirmed by characteristics of subject classification for any concrete phenomenon. i.e., it is necessary to divide notions by their information volume. The phytocenoses of environments contact zones reveal in more detail modern trends of ecosystems genesis at any level of their organization. Their research allows understanding the history of the phenomenon, to reveal the reasons of its appearing and to assess the dynamics of environment development in a whole at a concrete territory. Such communities can serve as a regional model of indication of existing processes and of changes occurred. Such changes can characterize of possible spontaneous dynamics and of anthropogenic environment destruction under definite ecological conditions. The following question will be always important: which is the nature of zonality, belts, extrazonality, as well as environmental genesis of environment determining zonality and extrazonality of vegetation? In this situation we must know the history of vegetation dynamics under climate changing for time in order to forecast the vector of the vegetation development in future. At present, this is an important program of nowadays ecology and biogeography in a global scale. In our opinion, paragenese of environments contact vegetation, as it is shown by results of our research, are to be considered as reflection of peculiarities of environmental conditions at a concrete territory inside of a natural zone. The classification of such phenomenon as communities of transitional natural conditions requires to establish definite criteria for the assessment of class (kind) of natural systems in which phytocenoses of environmental contact are related too. These results of the research of the phytocenoses diversity have first of all typological and classification importance for research of vegetation cover genesis at time.

To characterize phenomena of different quality under different conditions with the same notion means to confuse in the question in which phenomenon is considered. e.g., "forest edge" ecotone, "interzonal" ecotone or an ecotone inside a natural zone (subzone, altitude belt) are definitely phenomena of different quality presenting different environment. Paragenese phenomenon is more characteristic for intrazonal (extrazonal) formations. Paragenese includes and reflects at the same time the specifics of environment of vegetation formation on the background of climate dynamics and variability at a concrete time period.

\section{Acknowledgements}

We extend our thanks to scientists of the Laboratory of ecosystems bioindication (Siberian Institute of Plant 
Physiology and Biochemistry SB RAS) for the taking part in all our expeditions for the time.

\section{References}

[1] Lavrenko, Ye.M. (1980) Characteristics of Steppes as Vegetation Type. Vegetation of USSR European Part, Nauka, Leningrad, 200-206.

[2] Berg, L.S. (1947) Landscapes-Geographic Zones of USSR. Geografia, Moscow, 398.

[3] Ronginskaya, A.V. (1969) Structural-Dynamic Peculiarities and Productivity of Herb Meadow Short-Footed Forest Meadow in the Area of Lower Angara Region. Structural-Dynamic Peculiarities of Phytocenoses of Lower Angara Region. Nauka, Novosibirsk, 81-114.

[4] Yurtsev, B.A. (1981) Relict Steppe Systems of North-Western Asia. Nauka, Novosibirsk, 168.

[5] Peshkova, G.A. (1962) Relationship of Forest and Steppe Angara Region. Proceedings of East Siberian Biological Institute of USSR AS SB, 1, 90-99.

[6] Peshkova, G.A. (2001) Flora Genetic Analysis of Steppe Flora of South Siberia Mountains. Nauka, Novosibirsk, 192.

[7] Prein, Ya.P. (1892) Preliminary Report on Botanic Research of Balagansk District and Irkutsk City Suburbs. Proceedings of East-Siberian Branch of Russian Geographic Society, 23, 29-53.

[8] Sochava, V.B. (1963) Geographic Zonality and Polar Asymmetry. Proceedings of USSR AS, Geographic Series, 6, 112-123.

[9] Ecotones in the Biosphere (1997) Nauka, Moscow, 329.

[10] Weaver, J.E. and Clements, F.E. (1938) Plant Ecology. 2nd Edition, McGraw-Hill Book Co., 601.

[11] Walter, H. and Box, E. (1976) Global Classification of Natural Terrestrial Ecosystems. Vegetatio, 32, 1100-1106.

[12] Wiegand, T., Camarero, J.J., Rüger, N. and Gutiérrez, E. (2006) Abrupt Population Changes in Treeline Ecotones along Smooth Gradients. Journal of Ecology, 94, 880-892. http://dx.doi.org/10.1111/j.1365-2745.2006.01135.x

[13] Camarero, J.J., Gutiérrez, E. and Forth, M.J. (2006) Spatial Patterns of Plant Richness across Treeline Ecotones in the Pyrenees Reveal Different Locations for Richness and Tree Cover Boundaries. Global Ecology and Biogeography, 15, 182-191. http://dx.doi.org/10.1111/j.1466-822X.2006.00211.x

[14] Davis, A.M. (1977) The Prairie-Deciduous Forest Ecotone in the Upper Middle West. Annals of the Association of American Geographers, 67, 204-213. http://dx.doi.org/10.1111/j.1467-8306.1977.tb01133.x

[15] Baker, W. and Weisberg, P. (1997) Using GIS to Model Tree Population Parameters in the Rocky Mountain National Park Forest-Tundra Ecotones. Journal of Biogeography, 24, 513-526. http://dx.doi.org/10.1111/j.1365-2699.1997.00130.x

[16] Hansen-Bristow, K.J., Ives, J.D. and Wilson, J.P. (1988) Climatic Variability and Tree Response within Forest-Alpine Tundra Ecotone. Annals of the Association of American Geographers, 78, 505-519. http://dx.doi.org/10.1111/j.1467-8306.1988.tb00221.x

[17] Thomas, T., Lorenz, V. and Lorenz, D.C. (1988) Recent Vegetation Change along the Forest/Steppe Ecotone of Northern Patagonia. Annals of the Association of American Geographers, 78, 93-111. http://dx.doi.org/10.1111/j.1467-8306.1988.tb00193.x

[18] Bossuyt, B., Hermy, M. and Deckers, J. (1999) Migration of Herbaceous Plant Species across Ancient-Recent Forest Ecotones in Central Belgium. Journal of Ecology, 87, 629-638. http://dx.doi.org/10.1046/j.1365-2745.1999.00379.x

[19] Sjögersten, S., Turnert, B.L., Mahieut, N., Condrons, L.M. and Wookey, P.A. (2003) Soil Organic Matter Biochemistry and Potential Susceptibility to Climatic Change across the Forest-Tundra Ecotone in the Fennoscandian Mountains. Global Change Biology, 9, 759-772. http://dx.doi.org/10.1046/j.1365-2486.2003.00598.x

[20] Holtmeir, F.K. and Broll, G. (2005) Sensitive and Response of Northern Hemisphere Altitudinal and Polar Treelines to Environmental Change at Landscape and Local Scales. Global Ecology and Biogeography, 14, 395-410. http://dx.doi.org/10.1111/j.1466-822X.2005.00168.x

[21] Galaziy, G.I. (1954) Vertical Boundary of Wood Vegetation in East Siberia Mountains and Its Dynamics. Geobotanika, 9, 210-325.

[22] (1977) Correlative Ecological-Phytocenotic Map (Scale 1: 7,500,000). Irkutsk, 1 Sheet.

[23] (1972) Vegetation Map of the South of East Siberia (Scale 1: 1,500,000). Moscow, 4 Sheets.

[24] Steppes of Eurasia (1991) Nauka, Leningrad, 145.

[25] Milkov, F.N. (1966) Paragenetic Landscape Systems. Scientific Issues of Voronezh Branch of USSR Geographic Society, Voronezh, 6-18.

[26] Ivanovsky, L.N. (2001) Paragenese and Paragenesis of Mountain Relief of Siberian South. Institute of Geography of 
RAS SB, Irkutsk, 142.

[27] Kulikov, A.I., Bazhenov, V.S. and Ivanov, N.V. (2006) Paragenesis and Paradynamism of Soils. Buryat Scientific Center of RAS SB, Ulan-Ude, 280.

[28] Yarotsky, G.P. and Tarasov, A.V. (2008) Geological Criteria While Determining Boundaries of Specially Protected Areas. Geoecology, Engineering Geology, Hydrogeology, Geocryology, 2, 124-129.

[29] Yevdokimov, L.A. (1979) Materials on Paragenese of Vegetation at Phytocenotic Level. Morphology and Dynamics of Vegetation Cover, 229, 11-16.

[30] Vasilyev, S.V. (2007) Paragenesis. Forest and Swamp Landscapes of Western Siberia, Tomsk, 24-29.

[31] Steppes of Central Asia (2002) Nauka, Novosibirsk, 296.

[32] Natural Conditions of North-Eastern Pre-Baikal (1976) Novosibirsk, 368.

[33] Vegetation of Riverine Ecosystems of North Pre-Baikal (1992) Nauka, Novosibirsk, 174.

[34] Preobrazhensky, V.S., Fadeeva, N.V., Mukhina, L.I. and Tomilov, G.M. (1959) Land Types and Natural Division into Areas in Buryat Republic. Moscow, 218. 
Scientific Research Publishing (SCIRP) is one of the largest Open Access journal publishers. It is currently publishing more than 200 open access, online, peer-reviewed journals covering a wide range of academic disciplines. SCIRP serves the worldwide academic communities and contributes to the progress and application of science with its publication.

Other selected journals from SCIRP are listed as below. Submit your manuscript to us via either submit@scirp.org or Online Submission Portal.
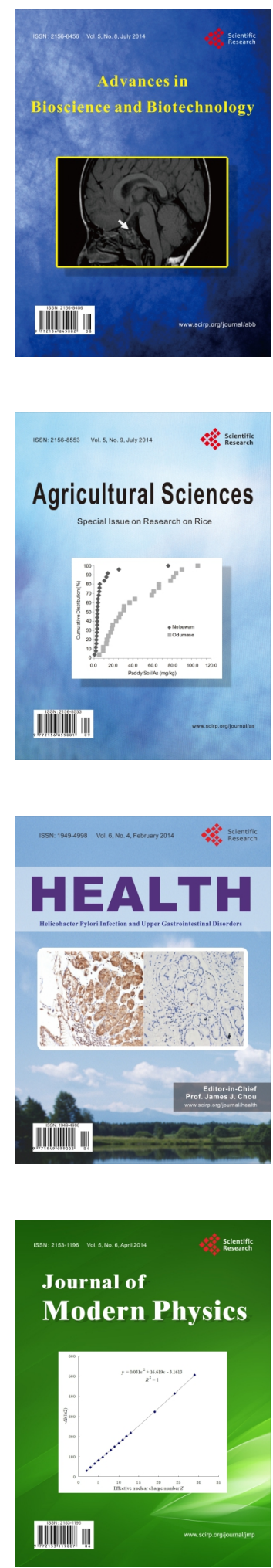
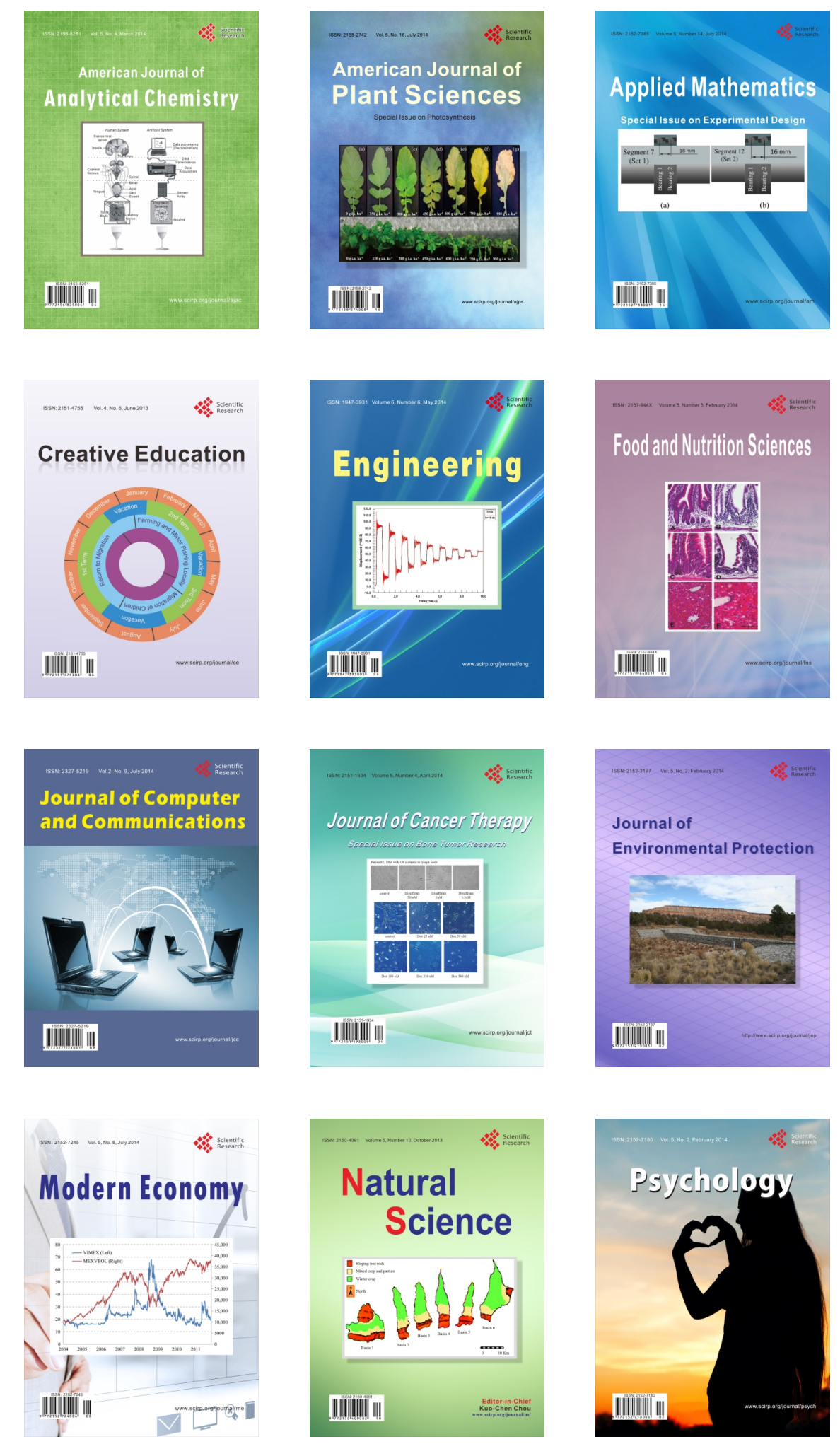